medRxiv preprint doi: https://doi.org/10.1101/2021.01.29.21250804; this version posted February 1, 2021. The copyright holder for this preprint (which was not certified by peer review) is the author/funder, who has granted medRxiv a license to display the preprint in perpetuity.

It is made available under a CC-BY-ND 4.0 International license.

\title{
A mathematical model to estimate percentage secondary infections from margin of error of diagnostic sensitivity: Useful tool for regulatory agencies to assess the risk of propagation due to false negative outcome of diagnostics
}

Azhahianambi, $\mathrm{P}^{1,2^{*}}$, Karthik, $\mathrm{K}^{2}$., Aravindh Babu, $\mathrm{RP}^{1,3}$., Senthil kumar, $\mathrm{TMA}^{1,2}$., Balachandran, $\mathrm{C}^{4}$ and Dhinakar Raj, $\mathrm{G}^{1^{*}}$

${ }^{1}$ Translational Research Platform for Veterinary Biologicals, Centre for Animal Health Studies, Tamil Nadu Veterinary and Animal Sciences University, Madhavaram, Chennai-600 051

${ }^{2}$ Central University Laboratory, Tamil Nadu Veterinary and Animal Sciences University, Madhavaram, Chennai-600 051

${ }^{3}$ Laboratory Animal Medicine, Centre for Animal Health Studies, Tamil Nadu Veterinary and Animal Sciences University, Madhavaram, Chennai-600 051

${ }^{4}$ Tamil Nadu Veterinary and Animal Sciences University, Madhavaram, Chennai-600 051

Corresponding authors: G. Dhinakar Raj,PhD: Email: dirtrpvb@gmail.com

Azhahianambi,P: Email: nambibio@gmail.com

\section{Abstract:}

False negative outcome of a diagnosis is one the major reasons for the dissemination of the diseases with high risk of propagation. Diagnostic sensitivity and the margin of error determine the false negative outcome of the diagnosis. A mathematical model had been developed to estimate the mean \% secondary infections based on the margin of error of diagnostic sensitivity, \% prevalence and $R_{0}$ value. This model recommends a diagnostic test with diagnostic sensitivity $\geq 96 \%$ and at least $92 \%$ lower bound limit of the $95 \% \mathrm{Cl}$ or $\leq 4 \%$ margin of error for a highly infectious diseases like COVID-19 to curb the secondary transmission of the infection due to false negative cases. Positive relationship was found between mean \% secondary infection and margin of error of sensitivity suggesting greater the margin of error of a diagnostic test sensitivity, higher the number of secondary infections in a population due to false negative cases. Negative correlation was found between number of COVID-19 test kits (>90\% sensitivity) with regulatory approval and margin of error $(R=-0.92, p=0.023)$ suggesting lesser the margin of error of a diagnostic test, higher the chances of getting approved by the regulatory agencies. However, there are no specific regulatory standards available for margin of error of the diagnostic sensitivity of COVID-19 diagnostic tests. Highly infectious disease such as COVID-19, certainly need specific regulatory standards on margin of error or $95 \% \mathrm{Cl}$ of the diagnostic sensitivity to curb the dissemination of the disease due to false negative cases and our model can be used to set the standards such as sensitivity, margin of error or lower bound limit of $95 \% \mathrm{Cl}$. 
medRxiv preprint doi: https://doi.org/10.1101/2021.01.29.21250804; this version posted February 1, 2021. The copyright holder for this preprint (which was not certified by peer review) is the author/funder, who has granted medRxiv a license to display the preprint in perpetuity.

It is made available under a CC-BY-ND 4.0 International license .

Keywords: COVID-19 diagnostics; $95 \% \mathrm{Cl}$; margin of error; diagnostic sensitivity; $\mathrm{R}_{0}$; risk of propagation; regulatory approval

\section{Introduction}

A perfect diagnostic test does not exist in real life and therefore diagnostic procedures can make only partial distinction between subjects with and without disease (Simundic, 2009). Diagnostic sensitivity and specificity of a diagnostic test are the metrices generally considered to assess the performance of the test in the real world or clinical condition. Sensitivity defines the proportion of true positive subjects with the disease in a total group of subjects with the disease and specificity defines proportion of subjects without the disease with negative test result in total of subjects without disease (Simundic, 2009). Among the diagnostic sensitivity and specificity, diagnostic sensitivity of a test is very critical in diagnosis of infectious diseases with high risk of propagation as false negative results could facilitate the community transmission of infectious diseases such as COVID-19. The precision of diagnostic sensitivity is also an important factor in the diagnosis of highly infectious diseases which is determined by $95 \%$ confidence interval $(\mathrm{Cl})$. Narrower the $95 \% \mathrm{Cl}$ interval, higher the precision of the diagnostic test. An ideal diagnostic test would have highest sensitivity and specificity with very narrow $95 \% \mathrm{Cl}$ which hardly exist in the real world. However, a test with diagnostic sensitivity close to $100 \%$ and very narrow $95 \% \mathrm{Cl}$ is need of the hour for the infectious disease such as COVID-19 with basic reproduction number $\left(R_{0}\right)$ greater than one. $R_{0}$ is defined as the expected number of secondary infections produced by a single infection in a completely susceptible population and If the mean $R_{0}>1$, the infection will spread exponentially. $R_{0}$ estimates for SARS virus infections have been reported to range between 2 and 5 . The $R_{0}$ value of SARS-CoV-2 infection during the early period of outbreak in China was estimated to be about 2.0 (Liu et al., 2020a) and the World Health Organization (WHO) estimate of $R_{0}$ value was 1.95 (1.4-2.5) (WHO, 2020). The recent studies claimed that the mean $R_{0}$ value of COVID-19 disease had been estimated to be 3.28 (Liu et al., 2020b) and the recently mutated SARS-CoV-2 B.1.1.7 lineage has $R_{0}$ value higher than the previous lineages. Higher the diagnostic sensitivity and narrower the $95 \% \mathrm{Cl}$ together churn out less false negative results and help in curbing the community transmission of highly infectious diseases with pandemic potential. A $95 \% \mathrm{Cl}$ is a range of values that can be $95 \%$ certain contains the true mean of the population and one can be $95 \%$ confident that the true population parameter is between the lower and upper limit values. US-FDA recommended that diagnostic sensitivity and specificity of all the tests to be reported with $95 \% \mathrm{Cl}$ (FDA, 2011; Hess et al., 2012). The confidence interval range of a diagnostic test can be simply summarised in a number as Margin of Error (M) which will help the clinicians to easily understand the precision of the 
medRxiv preprint doi: https://doi.org/10.1101/2021.01.29.21250804; this version posted February 1, 2021. The copyright holder for this preprint (which was not certified by peer review) is the author/funder, who has granted medRxiv a license to display the preprint in perpetuity.

It is made available under a CC-BY-ND 4.0 International license .

diagnostic test. The margin of error is simply one-half the width of the confidence interval, i.e. (Upper limit - Lower limit)/2 (Hess et al., 2012). Lower the margin of error of the diagnostic sensitivity and specificity, higher the precision of the diagnostic test. There is no commonly accepted standard for how small the margin of error should be for diagnostic test. In most of the social science studies a margin of error $<5 \%$ is the acceptable limit, but no such published or regulatory guidelines exists for the diagnostic tests used in the veterinary and medical practice (Royse, 2008; Sullivan, 2008; Royse et al., 2010). Though smaller margin of error are preferred for any diagnostic test, diagnostic test intended for the highly infectious diseases with $R_{0}>1$ needs specific recommendation from the regulatory agencies to restrict the rapid spread of the disease. Sensitivity and specificity of a diagnostic test may vary with the prevalence of disease in a population in which higher the prevalence of disease, higher the sensitivity and lower the specificity of the diagnostic test (Leeflang et al., 2013). A mathematical model had been developed to estimate the mean \% secondary infections based on the margin of error of diagnostic sensitivity, \% prevalence and $R_{0}$ value which can be used to set norms for diagnostic tests intended for diseases with high risk of propagation. This paper also discusses the role of diagnostic sensitivity and margin of error in the risk of propagation of the diseases with $R_{0}>1$ and emphasis the need to consider the margin of error of a diagnostic sensitivity of a diagnostic test as one of the parameters while approving the diagnostic tests associated with high risk of disease propagation.

\section{Materials and Methods}

\subsection{Mathematical model to estimate the mean secondary infection in relation to diagnostic sensitivity and margin of error}

The false negative cases are the persons carrying the infection but failed to be detected by the diagnostic test. Unlike false positive cases, the false negative cases carrying highly infectious pathogens such as COVID-19 virus could potentially act as community spreaders and source of secondary infections (Fig.1). If the $R_{0}$ value is 2.0 , every false negative person can potentially transmit the virus to 2 persons in a population. The mean $\%$ secondary infections related with the $\%$ false negative cases were estimated using a customised formula. The range of sensitivity in increment of one corresponding to the margin of error and length of range were kept as variable. The $R_{0}$ value and \% prevalence values were kept as constants. The $R_{0}$ value was kept as 2.0 in this formula as $R_{0}$ value of COVID-19 (WHO, 2020; Liu et al 2020a). Percentage prevalence of COVID-19 was assigned as $10 \%(0.10)$ as the mean weekly COVID-19 positive in USA was $9.6 \%$ (5\%-22\%) (CDC, 2020). Mean \% secondary infection due to false negative results was estimated for the diagnostic tests with sensitivity of $100 \%, 99 \%, 98 \%, 97 \%, 96 \%, 95 \%$ and $90 \%$ with margin of error ranging from $1 \%$ 
medRxiv preprint doi: https://doi.org/10.1101/2021.01.29.21250804; this version posted February 1, 2021. The copyright holder for this preprint (which was not certified by peer review) is the author/funder, who has granted medRxiv a license to display the preprint in perpetuity.

It is made available under a CC-BY-ND 4.0 International license.

to $10 \%$. The margin of error $(M)$ was calculated using the formula, Upper limit of $95 \% \mathrm{Cl}$ - Lower limit of $95 \% \mathrm{Cl}$ )/2 (Hess et al., 2012). The mean \% secondary infection for a diagnostic test with a sensitivity (i.e., $95 \%$ ) and margin of error (i.e., $2 \%$ ) was calculated as per the following formula.

Mean $\%$ secondary infection $=$

$\left.\left.\left.\left.\sum_{i=L L}^{U L}[((100-x i) X \% P) X R 0)+((100-(x i+1)) X \% P) X R 0\right)+\cdots+((100-U L) X \% P) X R 0\right)\right)\right] / N$

$x=95 \% \mathrm{Cl}$ range

i= Lower limit of the $95 \% \mathrm{Cl}$

UL= Upper limit of the $95 \% \mathrm{Cl}$

\% P= Percentage prevalence of COVID-19 (Assigned as 10\% prevalence (0.10), Mean weekly COVID19 positive in USA $9.6 \%(5 \%-22 \%))$

$\mathbf{R}_{\mathbf{0}}=$ Basic reproduction number (Assigned as constant value 2.0, $\mathbf{R}_{\mathbf{0}}$ value of SARS- CoV-2 infection)

$\mathrm{N}=$ Number of random populations

For easy calculation of the mean \% secondary infection for a diagnostic test with any range of sensitivity, variable $\mathrm{R}_{0}$ and \% prevalence, a R- software programme had been scripted based on the aforementioned formula.

The R software programme to calculate the secondary infection for a margin of error. Here the variables are ' $x$ ' and ' $n$ '; the constants are ' $y$ ' and ' $z$ '.

$x=95 \% \mathrm{Cl}$ as i.e., $\mathrm{c}(96: 100)$

$\mathrm{n}=$ number of random populations

$y=$ Percentage prevalence of COVID-19 (0.1)

$\mathbf{z}=\mathbf{R}_{\mathbf{0}}$ value $(\mathbf{2})$

$h=$ mean $\%$ secondary infection 


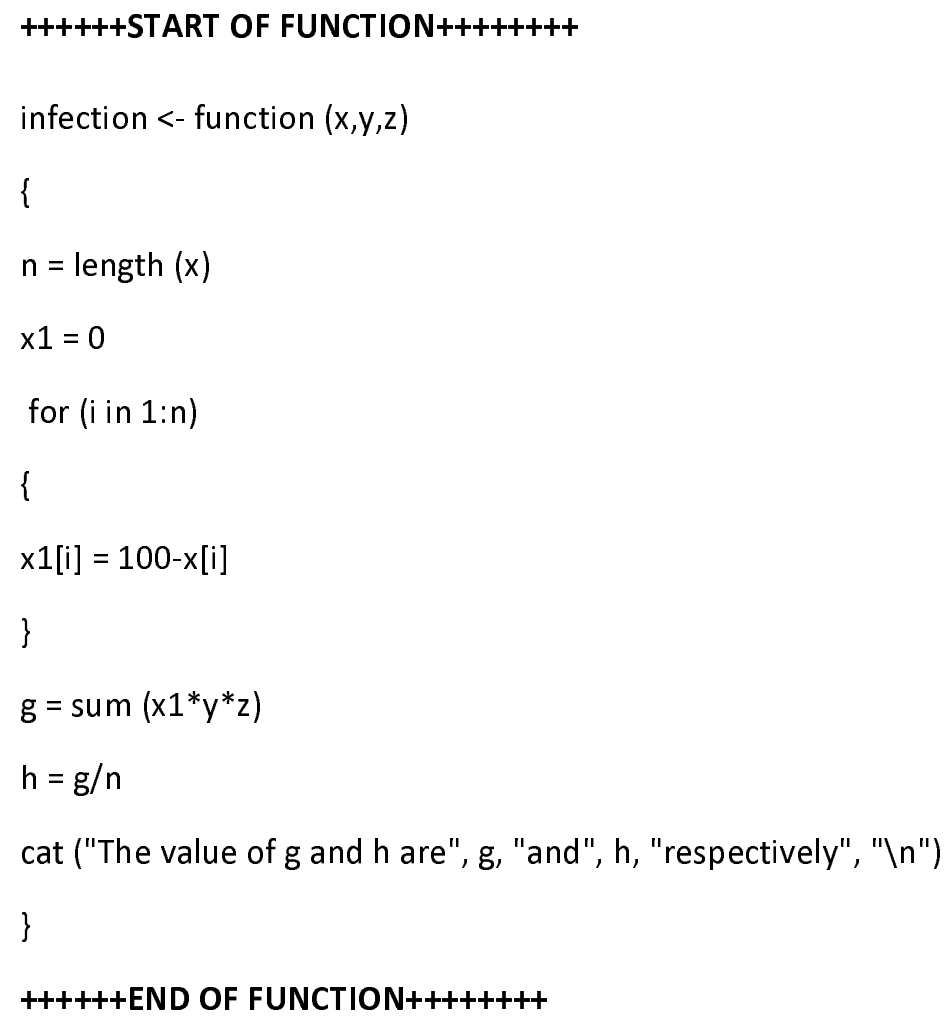

The range of $95 \% \mathrm{Cl}$ was taken as simple number range (i.e., 94\%-96\%) where the lower bound and upper bound limits are $94 \%$ and $96 \%$, respectively. The $\%$ secondary infections were calculated for the given $95 \% \mathrm{Cl}(94 \%-96 \%)$ by subtracting the lower limit value ( $\left.x_{i}=94 \%\right)$ from $100 \%$ sensitivity and multiplied by \% prevalence (0.10) and the product finally multiplied by $R_{0}$ value [(100-94) X $0.10 \mathrm{X}$ $2=1.2]$. Similarly, the $\%$ secondary infections were calculated for $95 \%\left(x_{i}+1\right)$ and $96 \%(U L)$. The mean $\%$ secondary infection was estimated as the mean of the 3 values. The diagnostic test with $95 \%$ diagnostic sensitivity $(95 \% \mathrm{Cl}, 94 \%-96 \%)$ is expected to have the population sensitivity from $94 \%$ to $96 \%$ with a confidence of $95 \%$. Here in the model, in a random of three infected populations with the disease prevalence of $10 \%$, the diagnostic test has been assumed to have $94 \%, 95 \%$ and $96 \%$ diagnostic sensitivity, respectively. The mean \% secondary infection from the false negative cases of the diagnostic test with $95 \%$ sensitivity $(95 \% \mathrm{Cl}, 94 \%-96 \%)$ in three random populations is estimated to be $1.0[(1.2+1.0+0.8) / 3]$. This model assumes that a diagnostic test with $95 \%$ diagnostic sensitivity 
medRxiv preprint doi: https://doi.org/10.1101/2021.01.29.21250804; this version posted February 1, 2021. The copyright holder for this preprint (which was not certified by peer review) is the author/funder, who has granted medRxiv a license to display the preprint in perpetuity.

It is made available under a CC-BY-ND 4.0 International license .

with margin of error $1(95 \% \mathrm{Cl}, 94 \%-96 \%)$ could facilitate the spread of an infectious disease $\left(R_{0}=2.0\right)$ up to $1 \%$ of the population as secondary infection due to false negative results. A diagnostic test with low false negative outcome which could spread an infectious disease such as COVID-19 to $<1 \%$ of the population is an ideal one.

\subsection{COVID-19 diagnostics data}

The data on antibody, antigen and Nucleic Acid Amplification Test (NAAT) based COVID-19 diagnostic kits, diagnostic sensitivity and specificity of the kits, margin of error and regulatory approval status of the COVID-19 diagnostic kits were obtained from finddx.com. The total number of antibody, antigen and NAAT based COVID-19 diagnostic kits with complete data set, kits with diagnostic sensitivity and specificity greater than $90 \%$, margin of error of the diagnostic kits and list of COVID19 diagnostic kits with regulatory approvals were obtained from finddx.com on $30^{\text {th }}$ November 2020 . The antibody and NAAT based COVID-19 diagnostic test kits with both diagnostic sensitivity and specificity greater than $90 \%$ were categorized based on the margin of error values.

\subsection{Statistical analysis}

The data generated from the model and the COVID-19 diagnostics data obtained from finddx.com were analysed by R-software R-4.0.2, GraphPad prism 7.0 and MS excel. Pearson correlation coefficient and coefficient of determination between the margin of error and mean \% secondary infections were calculated and line plot was plotted. Pearson correlation coefficient and coefficient of determination between the margin of error of diagnostic sensitivity and specificity and number of COVID-19 diagnostic kits approved by regulatory agencies with varying margin of error were calculated. Linear regression analysis of interval-valued data such as range of margin or error and number of approved kits in each range of margin of error was calculated using the upper, lower and midpoint values of the margin of error range (de Carvalho, et al., 2004)

\section{Results}

\subsection{Positive Correlation between margin of error of diagnostic test sensitivity and mean \% secondary infection}

The mean \% secondary infections were estimated for the diagnostic tests with sensitivity of $100 \%$, $99 \%, 98 \%, 97 \%, 96 \%, 95 \%$ and $90 \%$ with margin of error ranging from $1 \%$ to $10 \%$. The secondary infections are assumed to be due to the false negative cases spreading the infections in a community 
medRxiv preprint doi: https://doi.org/10.1101/2021.01.29.21250804; this version posted February 1, 2021. The copyright holder for this preprint (which was not certified by peer review) is the author/funder, who has granted medRxiv a license to display the preprint in perpetuity.

It is made available under a CC-BY-ND 4.0 International license .

where there is no herd immunity to the disease. The model suggests that diagnostic tests with sensitivity $\geq 96 \%$ with margin of error $\leq 4$, could be an ideal test with low false negative outcome that could spread the disease with $R_{0}$ value 2 and $10 \%$ prevalence to less than $1 \%$ of the population as secondary infection (Table. 1). A diagnostic test with risk of propagation of disease to less than $1 \%$ of population is expected to curb the spread of disease. Hence, less than $1 \%$ mean secondary infection was considered as the cut-off value to determine the diagnostic sensitivity, $95 \% \mathrm{Cl}$ and margin of error. The $\mathrm{R}$ software programme can be used to calculate the mean $\%$ secondary infection for any variable diagnostic sensitivity range, $R_{0}$ values and $\%$ prevalence ranges.

Positive correlation was found between mean \% secondary infection and margin of error $(R=1.0$, $p=0.0001$ (sensitivity $100 \%$ ); $R=0.94, p=0.00005$ (sensitivity $95 \%)$ ) suggesting greater the margin of error of a diagnostic test sensitivity, higher the number of secondary infections in a population due to false negative cases (Table. 1) (Fig.2).

This model recommends a diagnostic test with diagnostic sensitivity $\geq 96 \%$ and at least $92 \%$ lower bound limit of the $95 \% \mathrm{Cl}$ or $\leq 4 \%$ margin of error for highly infectious diseases like COVID-19 to curb the secondary transmission of the infection due to false negative cases. (Fig. 3). The recommended sensitivity and margin of error of a diagnostic test will change in accordance with the $R_{0}$ value and \% prevalence. Higher the $\mathrm{R}_{0}$ value and \% prevalence of the disease, we need to have a diagnostic test with higher sensitivity and narrow $95 \% \mathrm{Cl}$ or lower margin of error. High reproduction rate number and prevalence of an infectious disease are expected to drive the spread the disease to a greater number of people in a population and need a diagnostic test with highest sensitivity and lowest margin of error to prevent the secondary spread of the disease due to false negative outcome.

\subsection{Approved COVID-19 test kits with margin of error data}

Among 73,131 and 6 number of NAAT based, antibody based and antigen based COVID-19 diagnostic kits, respectively listed in the finddx.com, only 41,32 and 5 number of kits, respectively were available with complete data set including the $95 \% \mathrm{Cl}$ of sensitivity and specificity. NAAT based, antibody based and antigen based COVID-19 diagnostic kits with diagnostic sensitivity and specificity greater than 90\% were 29, 13 and 1, respectively (Table.2).

The number of COVID-19 test kits with diagnostic sensitivity and specificity greater than $90 \%$ with varying margin of error were binned into 6 different margin of error intervals (1\%-50\%). The number of COVID-19 test kits falling under different range of margin error were listed in Table.2. The number of NAAT based, antibody based and antigen based COVID-19 diagnostic kits with less than $5 \%$ margin of error and $>90 \%$ sensitivity was 10,7 and 0 , respectively. The number of NAAT based, antibody 
medRxiv preprint doi: https://doi.org/10.1101/2021.01.29.21250804; this version posted February 1, 2021. The copyright holder for this preprint (which was not certified by peer review) is the author/funder, who has granted medRxiv a license to display the preprint in perpetuity.

It is made available under a CC-BY-ND 4.0 International license .

based and antigen based COVID-19 diagnostic kits with less than $5 \%$ margin of error and $>90 \%$ specificity was 11,10 and 2, respectively (Table. 2).

\subsection{Negative correlation between the margin of error of diagnostic sensitivity and regulatory approval of COVID-19 test kits}

The number of approved NAAT and antibody based COVID-19 diagnostic kits with $>90 \%$ sensitivity and specificity binned into 6 different margin of error intervals, were subjected to linear regression analysis. Negative correlation was found between number of COVID-19 test kits (>90\% sensitivity) with regulatory approval and margin of error $(R=-0.92, p=0.023)$ suggesting lesser the margin of error of a diagnostic test, higher the chances of getting approved by the regulatory agencies (Table. 3) (Fig.4). The margin of error explained $85 \%$ variation in the regulatory approval process of the COVID-19 test kits $\left(R^{2}=0.85, p=0.023\right)$ suggesting the regulatory agencies such as US-FDA, CE-mark (EU), Health Canada, Australia TGA and Singapore HAS and Brazil ANVISA considering margin of error or $95 \% \mathrm{Cl}$ while approving the COVID-19 test kits. Though negative correlation was found between number of COVID-19 test kits ( $>90 \%$ specificity) with regulatory approval and margin of error ( $R=-$ $0.70, p=0.188$ ), it was not statistically significant (Table. 3) (Fig.4).

\section{Discussion}

Diagnostic tests for highly infectious diseases with low sensitivity and wider $95 \% \mathrm{Cl}$ or high margin of error are expected to yield more false negative results which could lead to rapid spread of the infections in community. A systematic review of the accuracy of COVID-19 tests reported false negative rates of between $2 \%$ and $29 \%$ (equating to sensitivity of $71-98 \%$ ), based on negative RT-PCR tests which were positive on repeat testing (Arevalo-Rodriguez et al., 2020). A person diagnosed negative for the infectious disease but actually carrying the infectious agent moving freely in the population and allowed to fly all over the world thus unwittingly transmitting the disease agent. Individuals with false negative results tend to relax physical distancing, wearing PPE and other personal measures designed to reduce the transmission of the virus to others (West et al., 2020) thus facilitate dissemination of the disease. Even diagnostic tests with perfect sensitivity but wider $95 \% \mathrm{Cl}$ or high margin of error could yield a greater number of false negative outcomes and that would facilitate the community transmission of the disease. Thus, margin of error of the diagnostic sensitivity of the test is an important parameter as the diagnostic sensitivity of the test.

Though it is well known that the person with false negative test result could act as a silent carrier of the infection and spread the infection, there are no study or model to show the relationship 
medRxiv preprint doi: https://doi.org/10.1101/2021.01.29.21250804; this version posted February 1, 2021. The copyright holder for this preprint (which was not certified by peer review) is the author/funder, who has granted medRxiv a license to display the preprint in perpetuity.

It is made available under a CC-BY-ND 4.0 International license .

between margin of error of diagnostic sensitivity which led to false negative outcome and secondary spread of the infection. Our model suggests the importance of margin of error of the diagnostic sensitivity in spreading the diseases through the false negative outcome which needs to be validated in field condition.

Though there are regulatory standards on $95 \% \mathrm{Cl}$ or margin of error for the influenza virus diagnosis, currently no regulatory standards on $95 \% \mathrm{Cl}$ or margin of error for the diagnostic sensitivity of COVID-19 diagnostics. FDA considers the observed sensitivity and specificity and their respective 95\% lower confidence bounds as part of device performance. As per FDA regulations, the sensitivity for the device testing for influenza A virus must be at least $90 \%$ with a lower bound of the $95 \% \mathrm{Cl}$ greater than or equal to $80 \%$. The sensitivity for the device testing for influenza B virus must be at least $80 \%$ with a lower bound of the $95 \% \mathrm{Cl}$ greater than or equal to 70 percent (FDA, 2020). The model used by FDA to estimate the recommended sensitivity and $95 \% \mathrm{Cl}$ is not known. Our model recommends a diagnostic test with diagnostic sensitivity $\geq 96 \%$ and at least $92 \%$ lower bound limit of the $95 \% \mathrm{Cl}$ or $\leq 4 \%$ margin of error for highly infectious diseases like COVID-19 to curb the secondary transmission of the infection due to false negative cases. This recommendation is based on the cut off value of risk of propagation of disease to less than $1 \%$ of population. This model can also be used as a base to arrive at the $95 \% \mathrm{Cl}$ or margin of error of the diagnostic sensitivity of other infectious diseases with known $R_{0}$ value or based on a presumptive $R_{0}$ value and \% prevalence of the disease.

A random population of varying sizes need to be tested to find out the best lower bound of $95 \% \mathrm{Cl}$ or margin of error of the diagnostic test (Russek-Cohen et al., 2011). The width of the $95 \% \mathrm{Cl}$ or margin of error based on a random sample will vary randomly and the $95 \% \mathrm{Cl}$ or margin of error may not always give an idea of the population parameter (Hazra, 2017). However, diagnostic tests intended for the diagnosis of highly infectious diseases with high risk of propagation such as COVID19 need stringent regulatory standards for pre- and post-market approval.

The negative correlation between the margin of error value of diagnostic sensitivity and number of approved COVID-19 kits suggestes that margin of error or $95 \% \mathrm{Cl}$ of the diagnostic sensitivity is considered by that the regulatory agencies while approving the test kits. Though majority of approved COVID-19 test kits fell under less than 5\% margin of error of sensitivity category, several approved kits with margin of error range $5 \%$ to $40 \%$ were also found and clearly suggests the lack of regulatory standards on the margin of error or $95 \% \mathrm{Cl}$ of diagnostic sensitivity/specificity of COVID19 test kits.

The regulatory approval of a diagnostic test intended for highly infectious disease such as COVID-19 should not only based on the sensitivity and specificity criteria, but also be based on the $95 \% \mathrm{Cl}$ or 
the margin of error as a diagnostic test with perfect sensitivity and wider $95 \% \mathrm{Cl}$ or high margin of error could lead to lot of false negative results which in turn facilitate the rapid spread of the diseases.

\section{Conclusion}

A mathematical model had been developed to estimate the mean \% secondary infections based on the margin of error of diagnostic sensitivity, \% prevalence and $R_{0}$ value. This model recommends a diagnostic test with diagnostic sensitivity $\geq 96 \%$ and at least $92 \%$ lower bound limit of the $95 \% \mathrm{Cl}$ or $\leq 4 \%$ margin of error for highly infectious diseases like COVID-19. Positive correlation was found between the estimated mean \% of secondary infection and margin of error and increase in margin of error of a diagnostic test would lead to rapid disease transmission due to false negative cases. Negative correlation was found between the number of COVID-19 diagnostic kits approved by regulatory agencies and margin of error of the test kits suggesting the chance of regulatory approval for a COVID-19 kits is higher when the margin of error is low. Though it is evident that margin of error or $95 \% \mathrm{Cl}$ plays a role in regulatory approval of a COVID-19 test kits, the norms and mathematical models followed by the regulatory agencies were not available. For COVID-19 like highly infectious disease with high risk of propagation certainly need specific regulatory standards on margin of error or $95 \% \mathrm{Cl}$ of the diagnostic sensitivity to curb the transmission of the disease due to false negative cases.

\section{Author contributions}

Azhahianambi, P: Conceptualization, Formula derivation, R-software programming, statistical analysis, interpretation of results and drafting the manuscript. Karthik, K: Data collection and compilation, data curation and formatting. Aravindh Babu, RP: Data curation, supplementary files, manuscript review. Senthil kumar, TMA: Data curation, manuscript review and funding. Balachandran, C and Dhinakar Raj, G: Conceptualization, funding, manuscript review

\section{Acknowledgment}

The funding received from Department of Biotechnology, Govt. of India for the project entitled

Translational Research Planform for Veterinary Biologicals- Phase III I BT/TRPVB/TANUVAS/2011/Phase III dated 17/09/2020) is duly acknowledged

\section{Declaration on conflict of Interest}


medRxiv preprint doi: https://doi.org/10.1101/2021.01.29.21250804; this version posted February 1, 2021. The copyright holder for this preprint (which was not certified by peer review) is the author/funder, who has granted medRxiv a license to display the preprint in perpetuity.

It is made available under a CC-BY-ND 4.0 International license .

The authors of this manuscript declare no conflict of interest

\section{References:}

Arevalo-Rodriguez, I., Buitrago-Garcia, D., Simancas-Racines, D., Zambrano-Achig, P., Del Campo, R., Ciapponi, A., Sued, O., Martinez-García, L., Rutjes, A.W., Low, N., Bossuyt, P.M., Perez-Molina, J.A., Zamora, J., 2020. False-negative results of initial RT-PCR assays for covid-19: a systematic review. PLoS One. 15(12), e0242958. doi: 10.1371/journal.pone.0242958.

CDC. 2020. COVIDView. A weekly surveillance summary of US COVID-19 acitvity. https://www.cdc.gov/coronavirus/2019-ncov/covid-data/covidview/index.html

de Carvalho F.A.T., Lima Neto E.A., Tenorio C.P. (2004) A New Method to Fit a Linear Regression Model for Interval-Valued Data. In: Biundo S., Frühwirth T., Palm G. (eds) KI 2004: Advances in Artificial Intelligence. KI 2004. Lecture Notes in Computer Science, vol 3238. Springer, Berlin, Heidelberg. https://doi.org/10.1007/978-3-540-30221-6_23

FDA. 2020. Code of Federal Regulations. Title 21, Volume 8. Revised as of April 1, 2020. CITE: 21CFR866.3328.

FDA. 2011. Statistical guidance on reporting results from studies evaluating diagnostic tests. Available from: http://www.fda.gov/MedicalDevices/DeviceRegulationandGuidance/ Guidance Documents/ucm071148.htm. Updated 6 January 2011; cited 8 December 2011

Hazra, A., 2017. Using the confidence interval confidently. J. Thorac. Dis. 9(10), 4124-4129. doi:10.21037/jtd.2017.09.14

Hess, A.S., Shardell, M., Johnson, J.K., Thom, K.A., Strassle, P., Netzer, G., Harris, A.D., 2012. Methods and recommendations for evaluating and reporting a new diagnostic test. Eur. J. Clin. Microbiol. Infect. Dis. 31(9), 2111- 2116. doi: 10.1007/s10096-012-1602-1.

Leeflang, M. M., Rutjes, A. W., Reitsma, J. B., Hooft, L., Bossuyt, P. M., 2013. Variation of a test's sensitivity and specificity with disease prevalence. CMAJ: Canadian Medical Association journal = journal de l'Association medicale canadienne, 185(11), E537-E544. https://doi.org/10.1503/cmaj.121286

Liu, Y., Eggo, R.M., Kucharski, A.J., 2020 Secondary attack rate and superspreading events for SARSCoV-2. Lancet.14, 395(10227), e47. doi: 10.1016/S0140-6736(20)30462-1.

Liu, Y., Gayle, A.A., Wilder-Smith, A., Rocklöv, J., 2020. The reproductive number of COVID-19 is higher compared to SARS coronavirus, J. Travel Med. 27(2), taaa021, https://doi.org/10.1093/jtm/taaa021.

Royse, D., 2008. Research methods in social work. 5. Thomson Brooks Cole; Belmont, CA: 2008.

Royse, D., Thyer, B.A., Padgett., D.K., 2010. Program evaluation: An introduction. 5. Wadsworth, Cengage Learning; Belmont, CA: 2010. 
medRxiv preprint doi: https://doi.org/10.1101/2021.01.29.21250804; this version posted February 1, 2021. The copyright holder for this preprint (which was not certified by peer review) is the author/funder, who has granted medRxiv a license to display the preprint in perpetuity. It is made available under a CC-BY-ND 4.0 International license .

Russek-Cohen, E., Feldblyum, T., Whitaker, K.B., Hojvat, S., 2011. FDA Perspectives on Diagnostic Device Clinical Studies for Respiratory Infections. Clin. Infect. Dis. 52(4), $305-$ S311. https://doi.org/10.1093/cid/cir056.

Šimundić, A.M., 2009. Measures of Diagnostic Accuracy: Basic Definitions. EJIFCC, 19(4), $203-211$.

Sullivan, L.M., 2008. Essentials of biostatistics in public health. 1. Jones and Bartlett; Sudbury, MA.

West, C.P., Montori, V.M., Sampathkumar, P., 2020. COVID-19 Testing: The Threat of False-Negative Results. Mayo Clin. Proc. 95(6),1127-1129. https://doi.org/10.1016/j.mayocp.2020.04.004.

WHO. 2020. Statement on the meeting of the International Health Regulations (2005) Emergency Committee regarding the outbreak of novel coronavirus 2019 ( $n$ - CoV) on 23 January 2020. Available from: https://www.who.int/news-room/detail/23-01-2020-statement-on-themeeting-of-the international-healthregulations-(2005)-emergency-committee-regarding-the-outbreak-ofnovelcoronavirus-(2019-ncov) 
Tables

Table 1. Estimated mean \% secondary infection at various diagnostic sensitivity and margin of error values where $R_{0}$ is 2.0 and relationship between margin of error and estimated mean \% secondary infection

\begin{tabular}{|c|c|c|c|c|}
\hline $95 \% \mathrm{Cl}$ & $\begin{array}{l}\text { Margin } \\
\text { of error }\end{array}$ & $\begin{array}{l}\text { Estimated mean \% } \\
\text { secondary infection }\end{array}$ & $\begin{array}{l}\text { Standard } \\
\text { Error of the } \\
\text { mean }\end{array}$ & $\begin{array}{c}\text { Correlation Coefficient } \\
(R) \text { and Coefficient of } \\
\text { determination }\left(R^{2}\right)\end{array}$ \\
\hline \multicolumn{5}{|c|}{ Diagnostic Sensitivity 99\%-100\% } \\
\hline $98-100$ & 1 & 0.2 & 0.14 & \multirow{5}{*}{$\begin{array}{c}\mathbf{R}=1.0 \\
P<0.00001\end{array}$} \\
\hline $96-100$ & 2 & 0.4 & 0.16 & \\
\hline 94-100 & 3 & 0.6 & 0.18 & \\
\hline $92-100$ & 4 & 0.8 & 0.19 & \\
\hline $90-100$ & 5 & 1 & 0.21 & \\
\hline $88-100$ & 6 & 1.2 & 0.23 & \multirow{5}{*}{$\begin{array}{c}\mathbf{R}^{2}=1.0 \\
p<0.00001\end{array}$} \\
\hline $86-100$ & 7 & 1.4 & 0.24 & \\
\hline $84-100$ & 8 & 1.6 & 0.25 & \\
\hline $82-100$ & 9 & 1.8 & 0.27 & \\
\hline $80-100$ & 10 & 2 & 0.26 & \\
\hline \multicolumn{5}{|c|}{ Diagnostic Sensitivity $98 \%$} \\
\hline $97-99$ & 1 & 0.4 & 0.10 & \multirow{5}{*}{$\begin{array}{c}\mathbf{R}=0.99 \\
P<0.00001\end{array}$} \\
\hline $96-100$ & 2 & 0.4 & 0.16 & \\
\hline $94-100$ & 3 & 0.6 & 0.18 & \\
\hline $92-100$ & 4 & 0.8 & 0.19 & \\
\hline $90-100$ & 5 & 1 & 0.21 & \\
\hline $88-100$ & 6 & 1.2 & 0.23 & \multirow{5}{*}{$\begin{array}{l}\mathbf{R}^{2}=0.99 \\
p<0.0001\end{array}$} \\
\hline $86-100$ & 7 & 1.4 & 0.24 & \\
\hline $84-100$ & 8 & 1.6 & 0.25 & \\
\hline $82-100$ & 9 & 1.8 & 0.27 & \\
\hline $80-100$ & 10 & 2 & 0.26 & \\
\hline \multicolumn{5}{|c|}{ Diagnostic Sensitivity 97\% } \\
\hline 96-98 & 1 & 0.6 & 0.08 & \multirow{5}{*}{$\begin{array}{c}\mathbf{R}=0.98 \\
P<0.00001\end{array}$} \\
\hline $95-99$ & 2 & 0.6 & 0.13 & \\
\hline $94-100$ & 3 & 0.6 & 0.18 & \\
\hline $92-100$ & 4 & 0.8 & 0.19 & \\
\hline $90-100$ & 5 & 1 & 0.21 & \\
\hline
\end{tabular}




\begin{tabular}{|c|c|c|c|c|}
\hline $88-100$ & 6 & 1.2 & 0.23 & \multirow{5}{*}{$\begin{array}{l}\mathbf{R}^{2}=0.96 \\
p<0.0001\end{array}$} \\
\hline $86-100$ & 7 & 1.4 & 0.24 & \\
\hline $84-100$ & 8 & 1.6 & 0.25 & \\
\hline $82-100$ & 9 & 1.8 & 0.27 & \\
\hline $80-100$ & 10 & 2 & 0.26 & \\
\hline \multicolumn{5}{|c|}{ Diagnostic Sensitivity 96\% } \\
\hline 95-97 & 1 & 0.8 & 0.07 & \multirow{10}{*}{$\begin{array}{c}\mathbf{R}=0.95 \\
p=0.00003\end{array}$} \\
\hline 94-98 & 2 & 0.8 & 0.11 & \\
\hline $93-99$ & 3 & 0.8 & 0.15 & \\
\hline $92-100$ & 4 & 0.8 & 0.19 & \\
\hline $90-100$ & 5 & 1 & 0.21 & \\
\hline $88-100$ & 6 & 1.2 & 0.23 & \\
\hline $86-100$ & 7 & 1.4 & 0.24 & \\
\hline $84-100$ & 8 & 1.6 & 0.25 & \\
\hline $82-100$ & 9 & 1.8 & 0.27 & \\
\hline $80-100$ & 10 & 2 & 0.26 & \\
\hline \multicolumn{5}{|c|}{ Diagnostic Sensitivity 95\% } \\
\hline $94-96$ & 1 & 1 & 0.14 & \multirow{10}{*}{$\begin{array}{c}\mathbf{R}=\mathbf{0 . 9 4} \\
p=0.00005\end{array}$} \\
\hline $93-97$ & 2 & 1 & 0.16 & \\
\hline $92-98$ & 3 & 1 & 0.18 & \\
\hline $91-99$ & 4 & 1 & 0.19 & \\
\hline $90-100$ & 5 & 1.1 & 0.19 & \\
\hline $88-100$ & 6 & 1.3 & 0.21 & \\
\hline $86-100$ & 7 & 1.5 & 0.22 & \\
\hline $84-100$ & 8 & 1.7 & 0.24 & \\
\hline $82-100$ & 9 & 1.9 & 0.25 & \\
\hline $80-100$ & 10 & 2.1 & 0.26 & \\
\hline \multicolumn{5}{|c|}{ Diagnostic Sensitivity 90\% } \\
\hline $89-91$ & 1 & 2 & 0.14 & \multirow{10}{*}{$\begin{array}{l}\mathbf{R}=\mathbf{0 . 5 2 ^ { \mathrm { NS } }} \\
P=0.123\end{array}$} \\
\hline $88-92$ & 2 & 2 & 0.16 & \\
\hline $87-93$ & 3 & 2 & 0.18 & \\
\hline 86-94 & 4 & 2 & 0.19 & \\
\hline $85-95$ & 5 & 2 & 0.21 & \\
\hline $84-96$ & 6 & 2 & 0.22 & \\
\hline $83-97$ & 7 & 2 & 0.24 & \\
\hline $82-98$ & 8 & 2 & 0.25 & \\
\hline $81-99$ & 9 & 2 & 0.27 & \\
\hline $80-100$ & 10 & 2.1 & 0.26 & \\
\hline
\end{tabular}

NS: Not significant at $5 \%$ and $10 \%$ level

*Sensitivity, $95 \% \mathrm{Cl}$ range and margin of error with less than $1 \%$ mean secondary infection is highlighted by shading 
Table 2. Approved COVID-19 diagnostic kits with diagnostic sensitivity and specificity greater than $90 \%$ listed in finddx.com

\begin{tabular}{|c|c|c|c|c|c|c|c|c|c|c|}
\hline \multicolumn{11}{|c|}{ Sensitivity $>\mathbf{9 0 \%}$ (Specificity varies) } \\
\hline \multirow[t]{2}{*}{ S.No } & \multirow{2}{*}{$\begin{array}{c}\text { Test } \\
\text { platform }\end{array}$} & \multirow{2}{*}{$\begin{array}{l}\text { Number of } \\
\text { Total kits } \\
\text { listed }\end{array}$} & \multirow{2}{*}{$\begin{array}{c}\text { No. of } \\
\text { kits with } \\
\text { sensitivity } \\
>90 \%\end{array}$} & \multirow{2}{*}{$\begin{array}{c}\% \text { of kits } \\
\text { with } \\
\text { sensitivity } \\
>90 \%\end{array}$} & \multicolumn{6}{|c|}{ No. of kits with margin of error } \\
\hline & & & & & $<5$ & $\begin{array}{l}5- \\
10\end{array}$ & $\begin{array}{c}10.1- \\
20\end{array}$ & $\begin{array}{c}20.1- \\
30\end{array}$ & $\begin{array}{c}30.1- \\
40\end{array}$ & $\begin{array}{c}40.1- \\
50\end{array}$ \\
\hline 1 & NAAT & 41 & $29 *$ & $70.7 \%$ & 10 & 4 & 6 & 4 & 1 & 0 \\
\hline 2 & $\begin{array}{c}\text { Antibody } \\
\text { test }\end{array}$ & 32 & 13 & $40.6 \%$ & 7 & 5 & 1 & 0 & 0 & 0 \\
\hline 3 & $\begin{array}{c}\text { Antigen } \\
\text { test }\end{array}$ & 5 & 2 & $40.0 \%$ & 0 & 2 & 0 & 0 & 0 & 0 \\
\hline \multicolumn{11}{|c|}{ Specificity >90\% (Sensitivity varies) } \\
\hline \multirow[t]{2}{*}{ S.No } & \multirow{2}{*}{$\begin{array}{c}\text { Test } \\
\text { platform }\end{array}$} & \multirow{2}{*}{$\begin{array}{c}\text { Number of } \\
\text { Total kits } \\
\text { available } \\
\text { at } \\
\text { finddx.com }\end{array}$} & \multirow{2}{*}{$\begin{array}{c}\text { No. of } \\
\text { kits with } \\
\text { sensitivity } \\
>90 \%\end{array}$} & \multirow{2}{*}{$\begin{array}{c}\% \text { of kits } \\
\text { with } \\
\text { sensitivity } \\
>90 \%\end{array}$} & \multicolumn{6}{|c|}{ No. of kits with margin of error } \\
\hline & & & & & $<5$ & $\begin{array}{l}5- \\
10\end{array}$ & $\begin{array}{c}10.1- \\
20\end{array}$ & $\begin{array}{c}20.1- \\
30\end{array}$ & $\begin{array}{c}30.1- \\
40\end{array}$ & $\begin{array}{c}40.1- \\
50\end{array}$ \\
\hline 1 & NAAT & 41 & $29 *$ & $70.7 \%$ & 11 & 3 & 2 & 0 & 2 & 7 \\
\hline 2 & $\begin{array}{c}\text { Antibody } \\
\text { test }\end{array}$ & 32 & 13 & $40.6 \%$ & 10 & 2 & 0 & 1 & 0 & 0 \\
\hline 3 & $\begin{array}{c}\text { Antigen } \\
\text { test }\end{array}$ & 5 & 1 & $40.0 \%$ & 2 & 0 & 0 & 0 & 0 & 0 \\
\hline
\end{tabular}

*4 kits have margin of error greater than 50.0 
Table 3. Margin of error of NAAT based and antibody-based COVID-19 test kits with regulatory approval and relationship between margin of error and number of regulatory approved COVID-19 test kits

\begin{tabular}{|c|c|c|c|c|c|c|c|}
\hline \multicolumn{8}{|c|}{$*$ Diagnostic sensitivity $>90 \%$} \\
\hline & $M<5$ & $M=5-10$ & $M=10.1-20$ & $M=20.1-30$ & $M=30.1-40$ & ${ }^{*} \mathbf{R}$ & $* * \mathbf{R}^{2}$ \\
\hline $\begin{array}{l}\text { Number of } \\
\text { approved } \\
\text { NAAT } \\
\text { based tests }\end{array}$ & 10 & 4 & 6 & 4 & 1 & -0.92 & 0.85 \\
\hline $\begin{array}{l}\text { Number of } \\
\text { approved } \\
\text { Antibody } \\
\text { based tests }\end{array}$ & 7 & 5 & 1 & 0 & 0 & $(p=0.023)$ & $(p=0.023)$ \\
\hline Total & 17 & 9 & 7 & 4 & 1 & & \\
\hline \multicolumn{8}{|c|}{ Diagnostic specificity > 90\% } \\
\hline & $M<5$ & $M=5-10$ & $M=10.1-20$ & $M=20.1-30$ & $M=30.1-40$ & ${ }^{*} \mathbf{R}$ & $* * \mathrm{R}^{2}$ \\
\hline $\begin{array}{l}\text { Number of } \\
\text { approved } \\
\text { NAAT } \\
\text { based tests }\end{array}$ & 11 & 3 & 2 & 0 & 2 & $-0.70^{N S}$ & $0.49^{N S}$ \\
\hline $\begin{array}{l}\text { Number of } \\
\text { approved } \\
\text { Antibody } \\
\text { based tests }\end{array}$ & 10 & 2 & 0 & 1 & 0 & $(p=0.188)$ & $(p=0.186)$ \\
\hline Total & 21 & 5 & 2 & 1 & 2 & & \\
\hline \multicolumn{8}{|c|}{$\begin{array}{l}\text { * Pearson correlation coefficient }(R) \text { between the midpoints of margin of error and number of } \\
\text { approved kits in each range of margin of error }\end{array}$} \\
\hline
\end{tabular}


medRxiv preprint doi: https://doi.org/10.1101/2021.01.29.21250804; this version posted February 1, 2021. The copyright holder for this preprint (which was not certified by peer review) is the author/funder, who has granted medRxiv a license to display the preprint in perpetuity.

It is made available under a CC-BY-ND 4.0 International license .

Figures

Fig 1: Diagram explaining the risk of propagation of highly infectious diseases such as COVID-19 due to false negative outcome of diagnosis

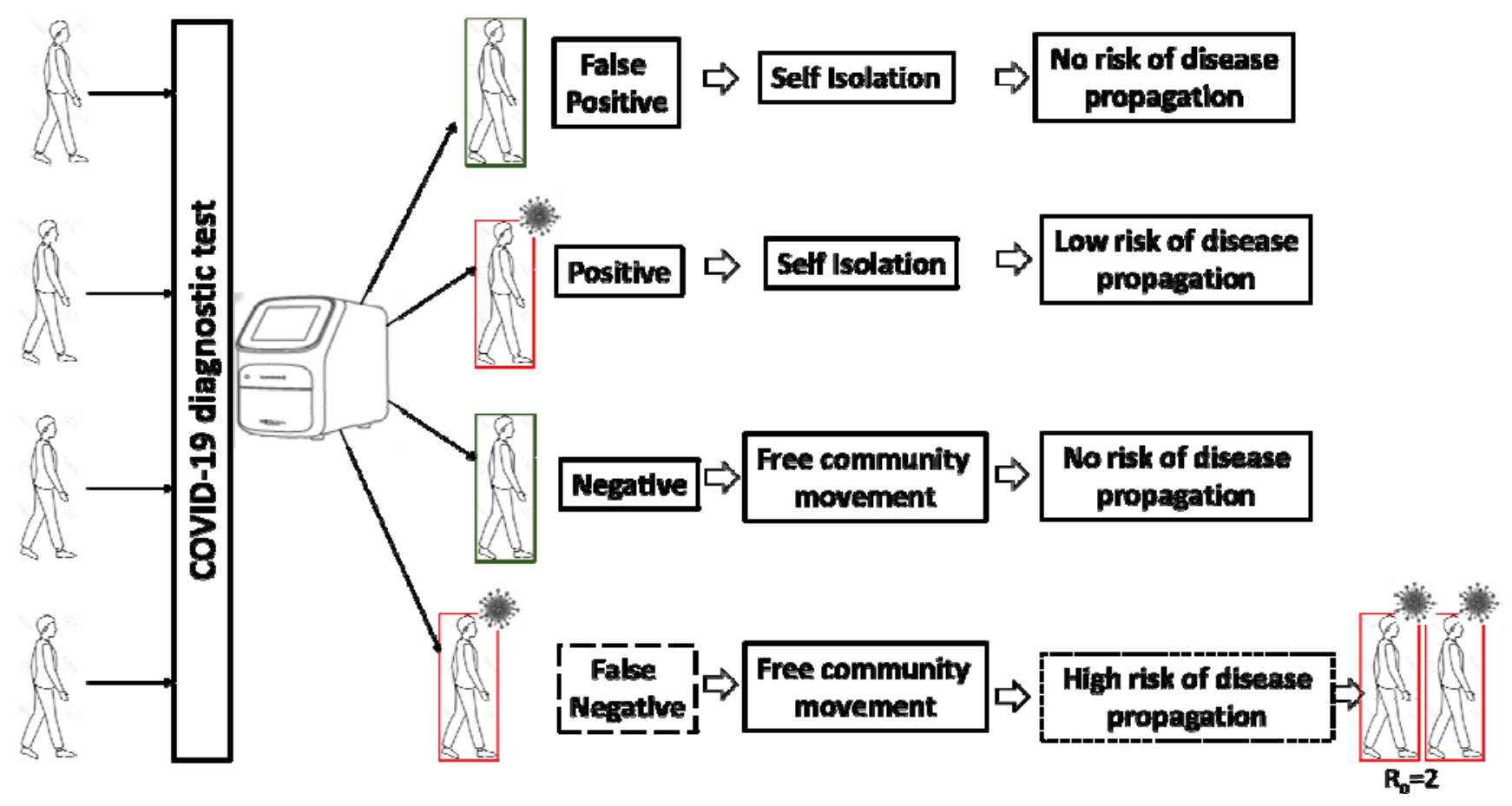


Fig. 2: Relationship between the estimated $\%$ mean secondary infections and margin of error where $\%$ prevalence of the disease is $10 \%$ and $\mathrm{R}_{0}$ is 2.0

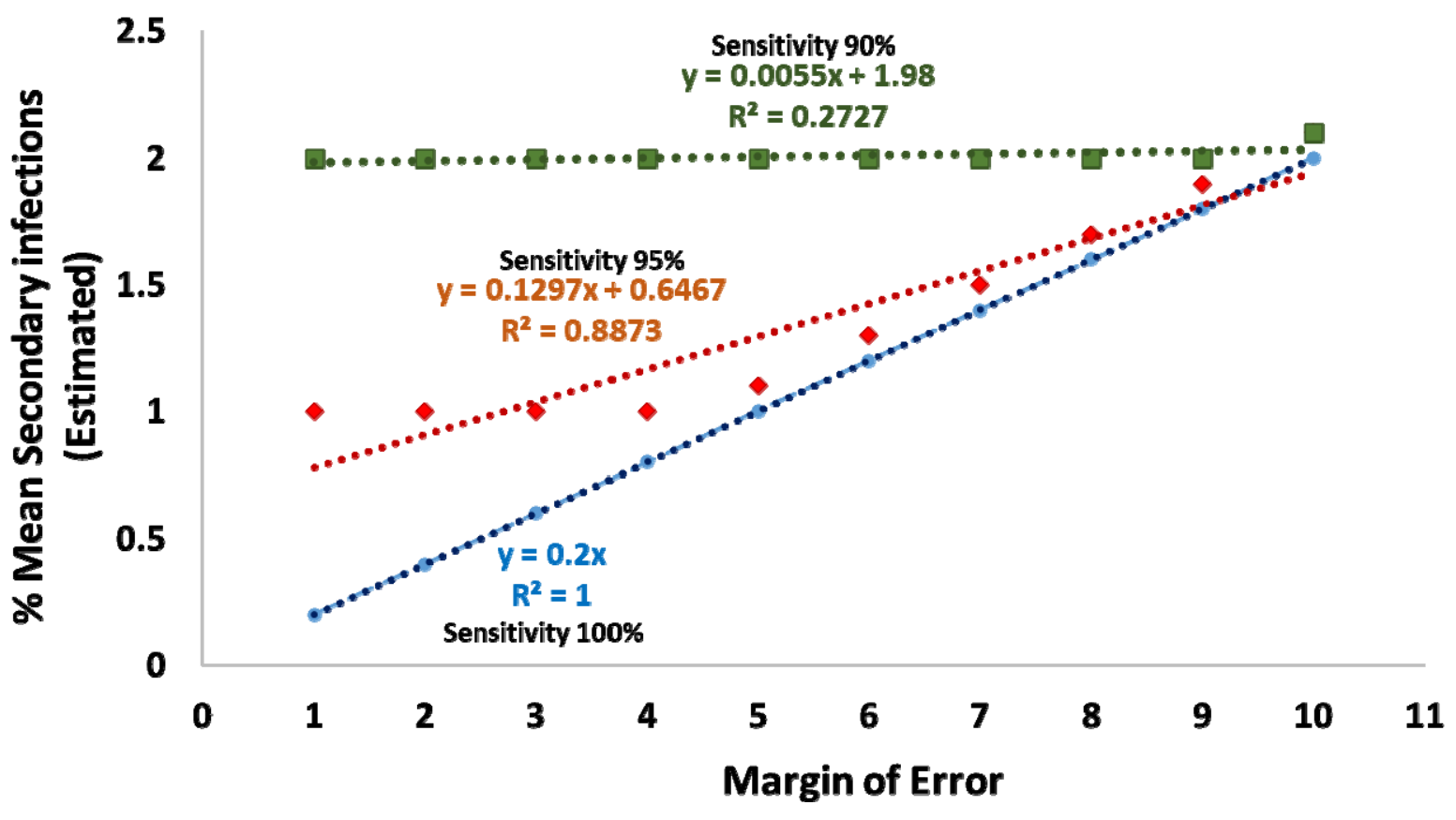


Fig. 3: Estimated $\%$ mean secondary infections in different diagnostic sensitivity and margin of error where \% prevalence of the disease is $10 \%$ and $\mathrm{R}_{0}$ is 2.0

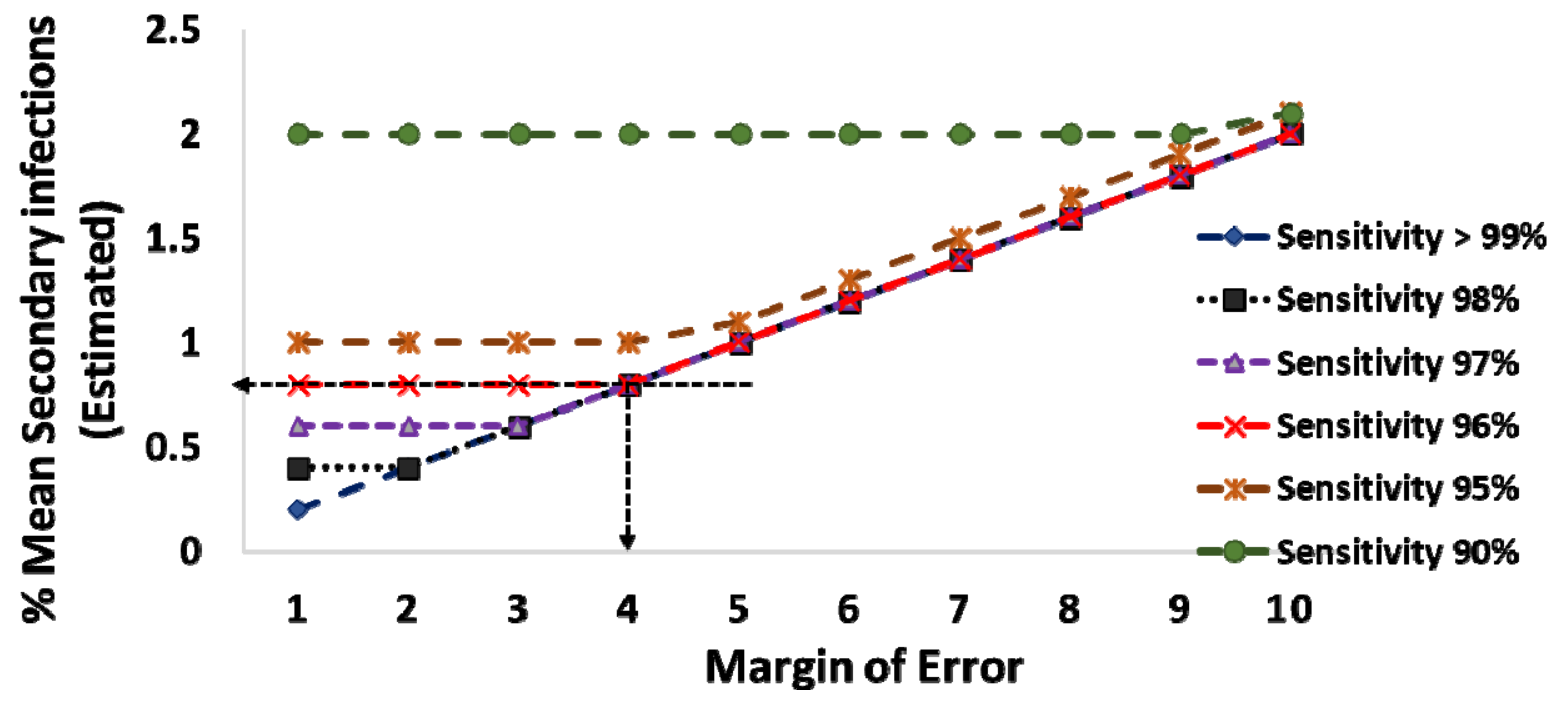


Fig. 4: Relationship between the number of COVID-19 diagnostics kits approved by

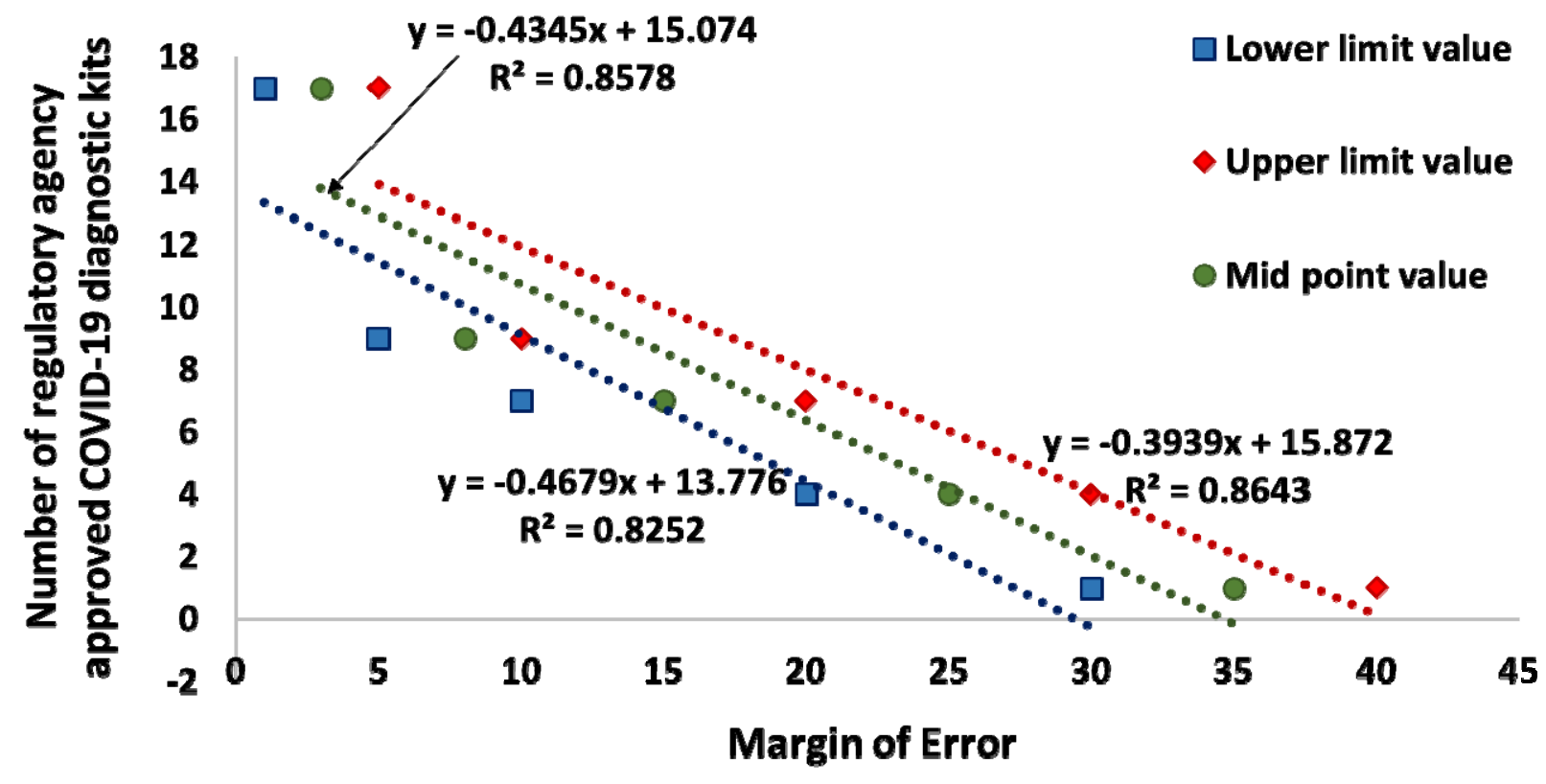

regulatory agencies and margin of error 
Diagram explaining the risk of propagation of highly infectious diseases such as COVID-19 due to false neg me of diagnosis

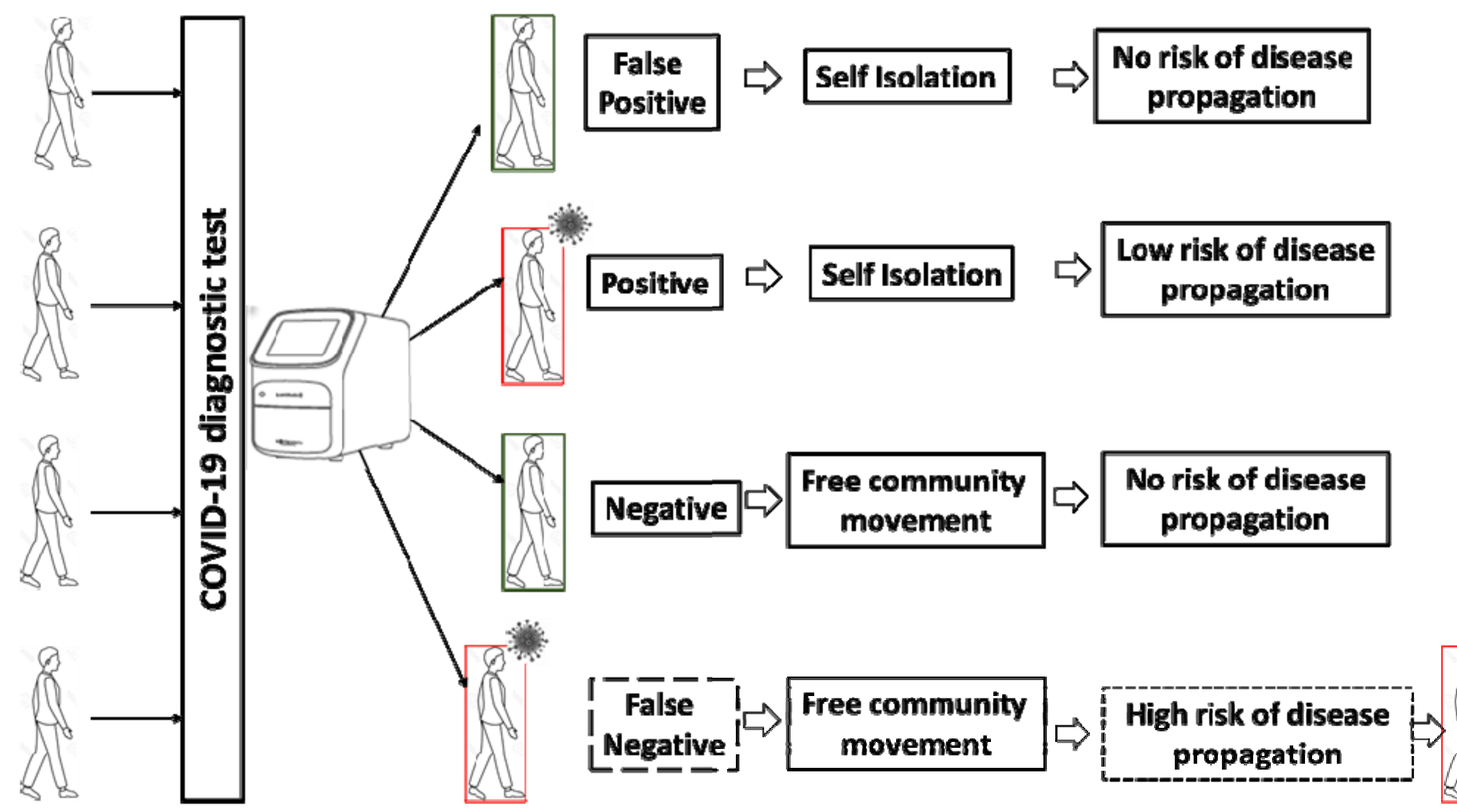


2: Relationship between the estimated \% mean secondary infections and margin of error where $\%$ preval $\epsilon_{0}^{\circ}$ re disease is $10 \%$ and $R_{0}$ is 2.0

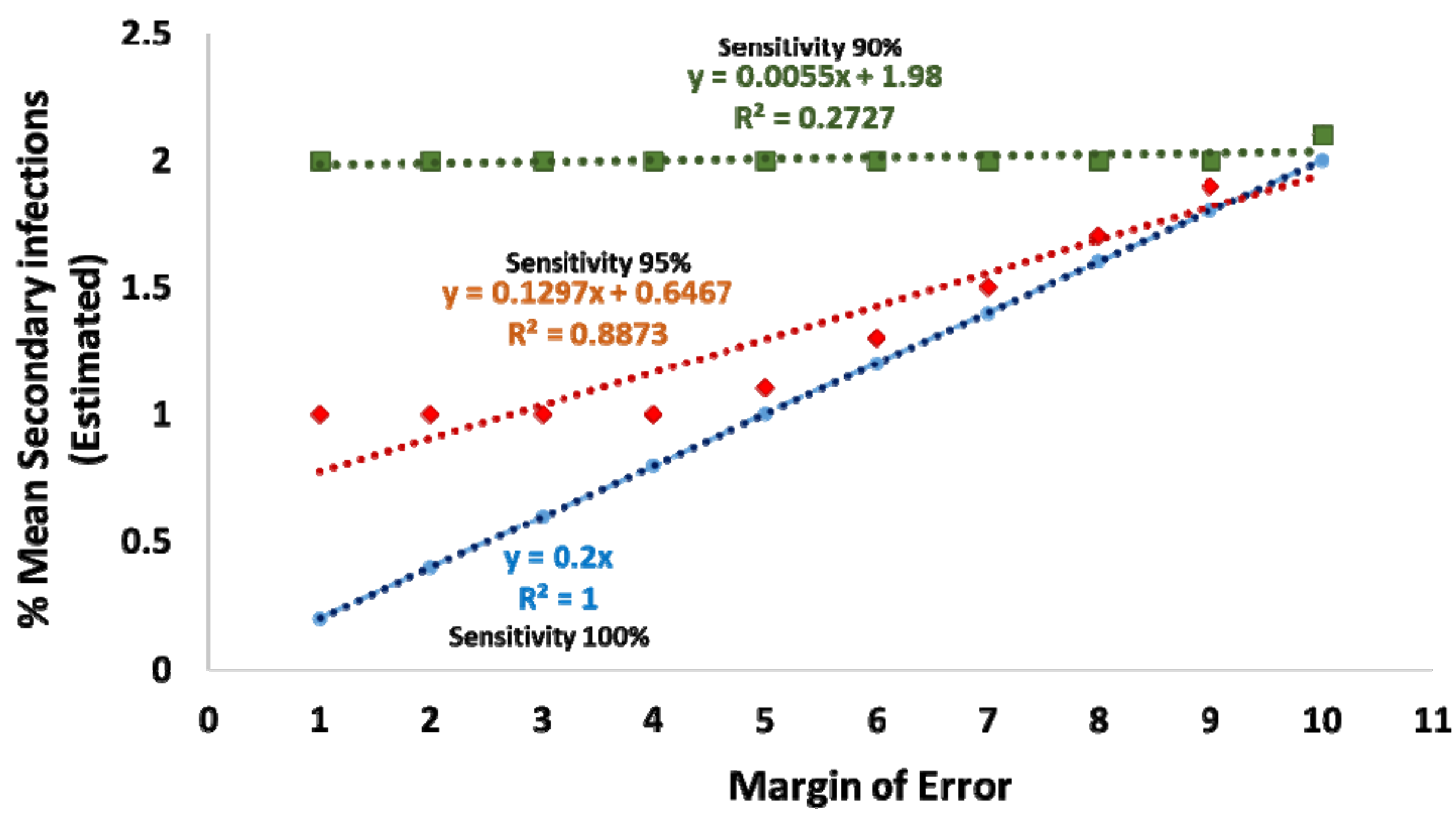


Estimated \% mean secondary infections in different diagnostic sensitivity and margin of error where \% lence of the disease is $10 \%$ and $R_{0}$ is 2.0

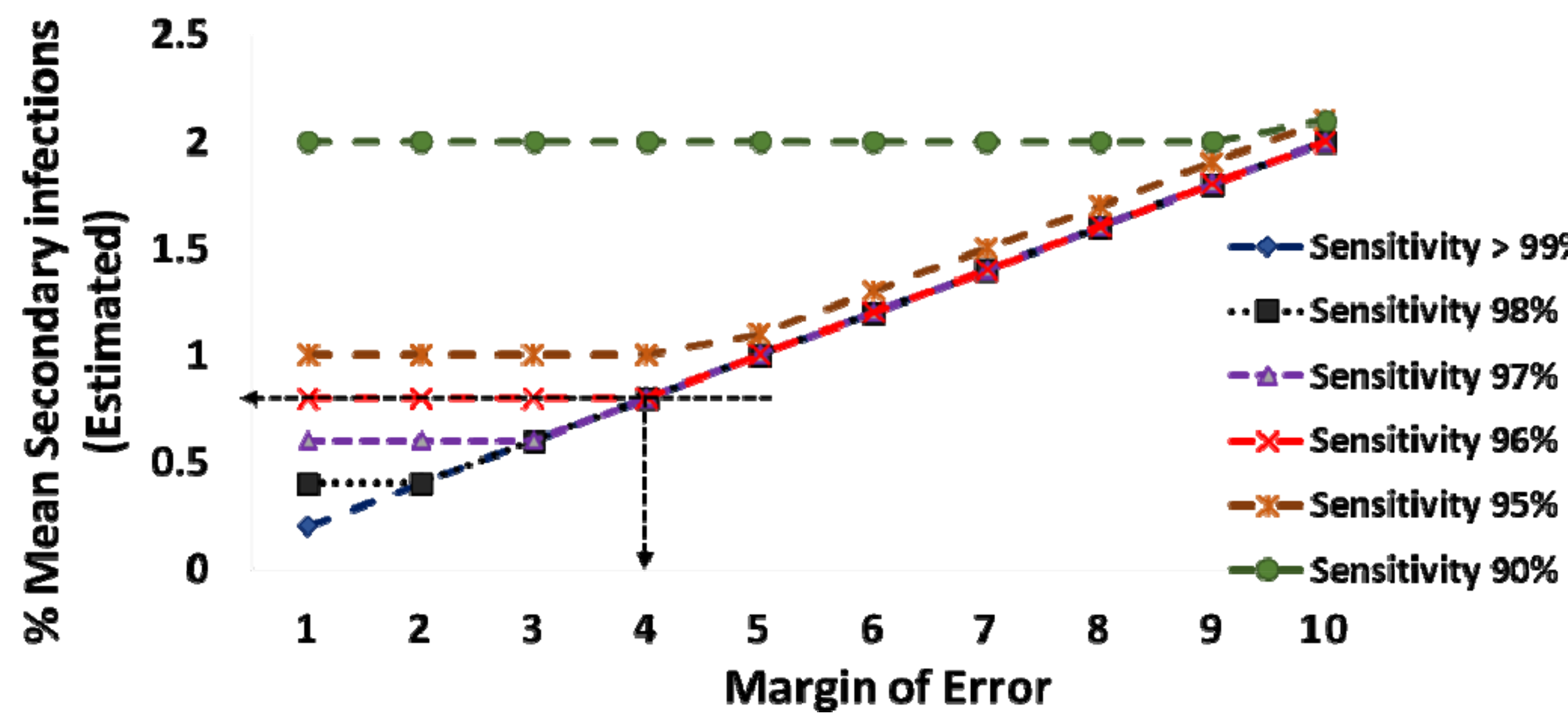




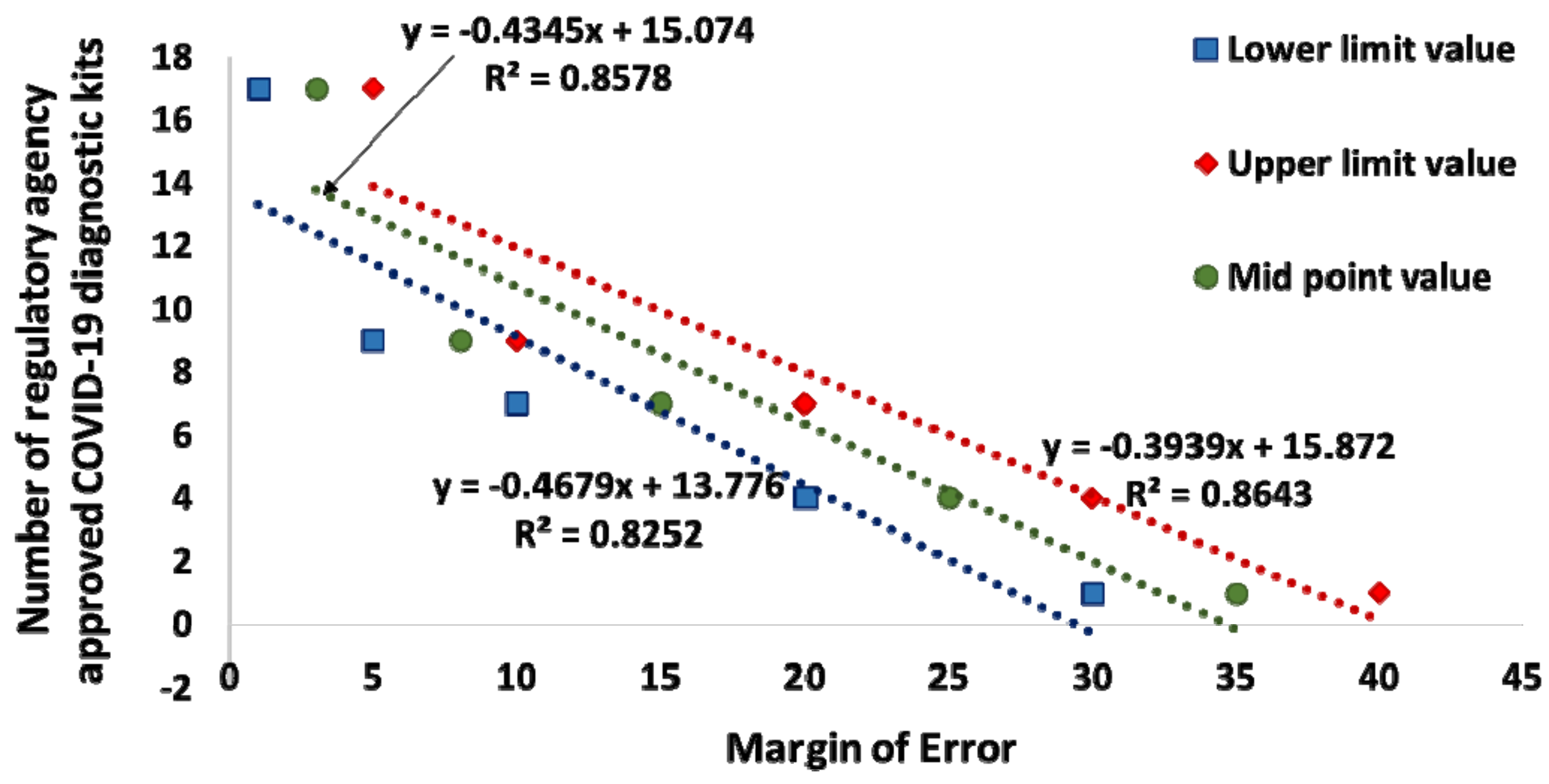

